\title{
SEMANTIC RELATIONS BETWEEN LEGAL TERMS. A CASE STUDY OF THE INTRALINGUAL RELATION OF SYNONYMY ${ }^{1}$
}

\begin{abstract}
The author intends to present a possibility of parametrising legal terminology in order to reveal semantic and systemic relations at the intralingual and interlingual levels. The scope of the research comprises selected legal terminology from the following legal systems: Polish, British, American and European Union. The research methods used include: (i) the analysis of comparable texts, (ii) the method of parametrisation of the legal linguistic reality, (iii) the concept of adjusting translation to the communicative needs and requirements of the recipient community. The research hypothesis is that parametrisation of legal terminology in respect of semantic and systemic relations may be a useful tool in organising and comparing terminology for the purpose of legal translation. First the relation of synonymy binding terms at the intralingual and interlingual levels in the light of systemic and genre-related relations is discussed. The proposal is illustrated with examples of legal terms and the networks of relations binding them in English and Polish. The conclusions are that such an approach is systematic and provides a translator with information necessary to render communicatively efficient translations.
\end{abstract}

Keywords: legal terminology, legal translation, parametrisation of legal translation, parametrisation of legal terms, synonymy, quasi-synonymy

\section{Introduction}

The paper is intended to provide an insight into differences between terms, which are considered synonymous. In the wake of the fact that an absolute synonymy is rarely observed it seems important to appreciate the similarities and differences between legal terms because the choice of the term may affect communication in legal settings. The research material encompassed terminology from Polish, British, American and European Union legal instruments. In order to reveal differences between synonymous terms the parametric approach to comparison of legal terminology was ap- 
plied (Matulewska 2013). This approach is based on the following research methods:

1. the comparison of parallel texts (cf. Neubert 1996, Delisle et al. 1999, Lewandowska-Tomaszczyk 2005, Roald \& Whittaker 2010),

2. the analysis of comparable texts (cf. Neubert 1996, Delisle et al. 1999, Lewandowska-Tomaszczyk 2005, Roald \& Whittaker 2010),

3. the method of axiomatisation of the legal linguistic reality (Bogusławski 1986, Bańczerowski \& Matulewska 2012, Matulewska 2013),

4. the terminological analysis of the research material (empirical observation),

5. the concept of adjusting the target text to the communicative needs and requirements of the community of recipients (cf. Vermeer 2001, Šarčević, 2000, Kierzkowska 2002, Matulewska 2013),

6. the techniques of providing equivalents for non-equivalent or partially equivalent terminology (Newmark 1982, 1988, 1991, Kierzkowska 2002, Matulewska \& Nowak 2006, Matulewska 2007), and also

7. the analysis of pertinent literature.

\section{Parametrisation}

The parametric approach helps describe legal linguistic reality and its fragments systematically. First, the researcher observes the reality. On the basis of the findings obtained as a result of the empirical observations, it is possible to describe the reality. The objects observed may be compared and similarities and differences between them may be revealed if the relevant parameters are defined. Parameters (also called dimensions) are sets of properties. Each object of the reality may assume only one property from each parameter.

Properties from each dimension serve the purpose of characterising the objects existing in the legal communication space. In other words, characterisation is the operation of association of properties from specific dimensions to a specific object in legal communication. In the process of translation objects are compared with regard to their properties; therefore the properties belonging to one dimension must be comparable. If the properties cannot be compared they must belong to different dimensions. (Matulewska 2013: 107-108).

Each dimension is a set of homogenous properties called dimension properties, which indicates that the properties are of the same type and therefore are comparable and simultaneously mutually exclusive - thus the object can assume only one property from each dimension. (Matulewska 2013: 107). 
If we do not have sufficient information to decide which property characterises the object under scrutiny, the object assumes the property of indeterminacy. Additionally,

in some cases it is evident that certain properties from given dimensions will presuppose the choice of properties from other dimensions. Thus the property P1 from dimension A may necessarily presuppose the choice of the property P1 from dimension B. (Matulewska 2013: 108).

To summarise, dimensions are sets of properties assumed by analysed and compared objects of legal reality. In this paper the focus is directed at some selected systemic and genre-related dimensions in respect to the relation of synonymy. The list of dimensions analysed here is not exhaustive and serves only illustrative purposes.

\section{Relation of synonymy}

The relation of synonymy is a semantic relation and binds two terms with the same referential meaning - but not necessarily the same pragmatic meaning - which belong to the same part of speech and differ in spelling. In many publications, synonymy is perceived as a sort of semantic equivalence. However semantic equivalence should not be identified with translational equivalence due to the fact that the pragmatic aspects of meaning of lexical items may be vital for producing communicatively adequate messages in the target language. If one takes into consideration the conglomerate of meanings, which a given term may possess, and the fact that one may hardly find any terms with exactly the same conglomerate of meanings, it seems more appropriate to discuss quasi-synonymous terms rather than synonymous terms, especially in the context of specialised translation. To summarise, there are hardly any absolute synonyms, that is to say, terms that would have the same meanings and would be interchangeable in all communicative (situational) and syntactic contexts, which is illustrated by the examples discussed below.

It should be stressed here that one may discuss synonymy at the intralingual level - then one compares terms or expressions occurring in one natural language. One may also analyse synonymy at the interlingual level - then one compares terms or expressions occurring in at least two natural languages. It must be assumed here that if two terms from two natural languages are synonymous or almost synonymous they are equivalent. If they are almost synonymous the question arises as to the scope 


\section{Aleksandra Matulewska}

of differences between such interlingual synonyms. Parameters help establish the distance between analysed terms and thus facilitate making a decision whether the terms are in fact sufficiently equivalent for the purpose of translation. Furthermore, if there are more synonymous terms than one in a target language, parameters help ascertain which of the possible equivalents is closer in meaning (both referentially and pragmatically) to the source language term. In other words due to parameters one may closely scrutinise terms and choose a pair which is sufficiently equivalent or eliminate a pair which is not sufficiently equivalent for a given translation recipient.

\subsection{Parameter of lect}

A lect is understood here as "a mode of language manifestation" (Bańczerowski 1996: 16). It should also be remembered that lects may be distinguished considering various criteria so one may also discuss 'a standard lect (or the so called standard language), a colloquial lect, a dialect, a sociolect, an idiolect' (Bańczerowki 1996: 16). Additionally, each language for special purposes constitutes a separate lect e.g. economic lect. For the purpose of this paper the following lects are distinguished: vernacular lect, legal lect, etc.

\subsubsection{Synonymous terms occurring in vernacular and legal lects}

When one parameterises terminology in respect to the dimension of lect one may encounter two situations. The terms either belong to (i) the vernacular language or (ii) some language for special purposes.

Here are some examples of pairs of synonymous terms, of which one is used in vernacular language and the other in legal language. An example of such synonymous terms in Polish are bankructwo 'bankruptcy, insolvency' which is used in the colloquial language and upadtość 'bankruptcy, insolvency' which is a legal term. Analogously, the person who becomes bankrupt is called bankrut in colloquial language and upadty in the language of the law. Those terms do not differ in meaning. However, only one from each pair may be classified as belonging to the language for special purposes, that is to say, the legal language (legal lect). The relation of intralingual synonymy holds between the terms upadłość and bankructwo, but it is not an absolute synonymy, as the terms differ in respect to the dimensions of lect. Therefore, at the intralingual level, those terms may be considered synonymous but not absolutely and when rendering a translation for a recipient well versed in law the terms upadtość and upadty should be used rather than bankructwo and bankrut. 


\subsubsection{Synonymous terms occurring in legal and other special purposes' lects}

Synonymous terms may also occur in two languages for special purposes. For instance two Polish terms used in civil law, being umowa and kontrakt are bound by the relation of synonymy. The relation of intralingual synonymy binding those two terms in respect to the parameter of lect is presented below in Table 1.

\section{Table 1}

Intrasystemic semantic relation of synonymy at the intralingual level

\begin{tabular}{|l|l|l|}
\hline Legal system reality & synonyms & $\begin{array}{l}\text { Dimensions in respect of which the terms } \\
\text { assume different properties }\end{array}$ \\
\hline Civil law country: Poland & umowa & Lect: legal lect \\
\cline { 2 - 3 } & kontrakt & Lect: economic lect \\
\hline
\end{tabular}

Table 1 presents an intrasystemic semantic relation of synonymy at the intralingual level (for the Polish language) where synonymous terms umowa and kontrakt differ in respect to the dimension of lect, as one of the terms is used in legal language and the other in the language of economics. In other words, the relation of quasi-synonymy holds between the terms: kontrakt and umowa, as it is not an absolute synonymy because the terms differ in respect to the dimensions of lect. It should also be noted that some lawyers for instance Brzozowski claim that the term kontrakt (as used by legal academics) is used in reference to the civil law of obligation (Brzozowski in Eętowska (ed.) 2013: 420). It is also used to refer to international contracts concluded between states (Pazdan in Popiołek (ed.) 2013).

\subsection{Synonymy within legal lect}

\subsubsection{Lack of terminological consistency}

On many occasions despite the principle that law should be unambiguous and legal texts should be free from synonyms, lawyers fail to observe this rule and invent new terms for various purposes. In Poland numerous terms have been invented in order to avoid terminological repetitions, which in the vernacular or literary language are considered a feature of clumsy style and limited linguistic competence of the author of a text. Sometimes terms are created because there is a need to differentiate similar but not identi- 


\section{Aleksandra Matulewska}

cal phenomena. With the passage of time it frequently happens that the differentiation, once so vital, has lost its importance and the meanings of terms no longer differ. There are also situations in which various specialists introduce a new term to name a new object emerging in legal reality. For some time the doctrine tests those synonymous terms, and finally one of them begins to prevail, with the other still in use for some time. Mattila (2013: 144) claims that

Synonymy as a phenomenon stands opposite to polysemy: two or several terms express the same concept. For example, where magistrates arrange an inspection at the scene, legal French uses synonymous terms. These are visite des lieux, transport sur les lieux, descente sur les lieux or vue des lieux.

The English legal language in the course of its historical development was enriched and in a way burdened with the so-called synonymous strings that is to say strings of terms of various etymology but the same or almost the same meaning which are used even to this day. It is claimed that

The synonym habit in which legal draftsmen still excel had its background in real necessity: With the Anglo-French mixture of languages, coupled with the relics of Latin and Old English a certain amount of double occurrence of the same concepts seems quite unavoidable. How was the draftsman to make a choice between terms which were equally valid and acceptable? How could he be sure they were "equally valid" beyond reasonable doubt? The uncertainty made lawyers reluctant to make a choice between e.g. a French term (with an established definition behind it) and an English equivalent of less universal professional acceptance and would give each in a document to secure legal effect. [...] Nor was the practice of multiplying words restricted to legal language in medieval times. The habit is characteristic of most literary works of the time where it was used for ornamental purposes (and with a view to alliteration and rhyme) and it is certainly possible that the same motives were present in legal writing (Grøn 1992: 126-127).

Here are some examples of such synonymous strings which may be found in the English legal language:

1. agree and covenant - zgadzać się

2. annul and set aside - unieważniać i uchylać

3. any and all - wszelkie; jakiekolwiek i wszystkie

4. authorise and empower - upoważniać

5. bind and obligate - wiązać (obowiązkiem)

6. cancel, annul and set aside - anulować, unieważniać i uchylać

7. cease and desist - zaniechać i zaprzestać 
8. do and perform - robić i wykonywać

9. each and every - każdy

10. false and untrue - fałszywy i nieprawdziwy

11. fit and proper - właściwy i odpowiedni

12. force and effect - moc i skutek

13. give and grant - dać i przyznać

14. mind and memory - umysł i pamięć

15. new and novel - nowy

16. null and void and of no force and effect - nieważny i nieposiadający mocy prawnej

17. part and parcel - czesść

18. pay, satisfy and discharge (debts) - spłacić i zaspokoić

19. peace and quiet - spokój

20. request and require - żądać i wymagać

21. rest, residue and remainder - reszta i pozostała część

22. seriously and gravely - poważnie

23. sole and exclusive - wyłączny

24. terms and conditions - warunki

25. to have and to hold - mieć i posiadać

There were many reasons for using synonymous strings in the English legal language. However, two of them were most visible:

The first one is tradition, and the second one is precautionary. Tradition means that to sound like a professional lawyer, it is necessary to use such strings. Otherwise one might be accused of not knowing the language of the law. The second reason is more complicated as it has its roots in the English legal reality, Common Law and precedents. There is a saying that an English legal instrument (e.g. a contract) must 'stand alone'. This means that if any dispute arises, the court is to take into consideration the wording of a contract and not the prior communication between the parties. It also means that the court shall not make an investigation concerning the intentions of the parties. Therefore, it is much safer to use such a wording the interpretation of which is well known and beyond any doubt. If there are precedents stating how to interpret some particular strings of words, changing them may lead to a completely different interpretation. And as it is risky because the outcome is difficult to predict and no-one who signs a contract wants any risk, it is safer and strongly advisable to use tradition-sanctified strings of synonymous (or apparently synonymous) words and expressions. (Matulewska 2007).

Such cases of occurrence of almost absolute synonyms may also be found in Polish legal language. For instance the Polish legislator in the Polish Civil Code uses two pairs of synonymous terms interchangeably: (i) nieruchomość 


\section{Aleksandra Matulewska}

and rzecz nieruchoma as well (ii) ruchomość and rzecz ruchoma. Although the analysis of the Polish Civil Code and academic writings reveals that the terms are used absolutely interchangeably, it cannot be said about other legal genres e.g. land and mortgage registers where the term nieruchomość is used. At the same time the terms refer to exactly the same object of reality so there is no danger of causing communication problems if replacing one with the other.

\subsubsection{Parameter of time of text creation - synonymous terms in a diachronic perspective}

The translator should also be aware that it frequently happens that information sources gather terms without marking them in respect to diachronic changes. Therefore, we may frequently encounter dictionaries which contain entries which are synonymous as far as their referential meaning is concerned but when analysed closely they turn out to be pragmatically varied. Some of them may even be archaic and no longer in use. The in-depth diachronic analysis reveals that span of time in which a given term was used. In the case of legislation it is relatively easy to observe such changes. Here are some examples from three Polish statutes that is to say the Act of $29^{\text {th }}$ March 1926 on Copyright [Ustawa z dnia 29 marca 1926 r. o prawie autorskim], the Act of $10^{\text {th }}$ July 1952 on Copyright [Ustawa z dnia 10 lipca 1952 r. w prawie autorskim] and finally the Act of $4^{\text {th }}$ February 1994 on Copyright and Neighbouring Rights [Ustawa o prawie autorskim i prawach pokrewnych z dnia 4 lutego 1994 roku]. All three acts regulate the copyright issues but terminological changes which can be observed are significant and relate not only to the linguistic changes but also changes in reality in which we live (including technological development). The object of the copyright is called in English a work. In the first statute of 1926 it was called in Polish dzieło. Since 1952 the term utwór is used. Analogously musical works were called by the legislator kompozycje muzyczne 'lit. musical compositions' in the Act of 1926, uktady muzyczne 'lit. musical arrangements' in 1952 and utwory muzyczne 'lit. musical works' since 1994. The publisher used to be called naktadca in the Act of 1926, but he has been called wydawca since the Act of 1952. Quotations were called wyimki in the Act of 1926, wyjatki in the Act of 1952 and have been called cytaty since the Act of $1994 .^{2}$ The juxtaposition of diachronic changes in terminology resulting in the emergence of synonyms in the Polish language of copyright discussed above is presented in Table 2 below. 
Table 2

The juxtaposition of diachronic changes in terminology resulting in the emergence of synonyms in the Polish language of copyright

\begin{tabular}{|l|l|l|}
\hline dzieło & utwór & utwór \\
\hline kompozycje muzyczne & układ muzyczny & utwór muzyczny \\
\hline dzieła architektoniczne & utwory architektoniczne & $\begin{array}{l}\text { utwory architektoniczne, } \\
\text { architektoniczno-urbanistyczne } \\
\text { i urbanistyczne }\end{array}$ \\
\hline nakładca & wydawca & wydawca \\
\hline wyimki & wyjątki & cytaty \\
\hline
\end{tabular}

\subsubsection{Parameter of text genre. Legal-genre dependent synonymy}

Synonymous terms may also occur in various genres of texts. GoźdźRoszkowski (2012) turns readers' attention to an important, but frequently disregarded, aspect of legal language: namely, the fact that stylistic, grammatical and collocational features of texts belonging to different legal genres vary. Therefore he actually suggests that instead of discussing legal language or the language of the law, one should rather discuss the legal language of statutory instruments, the legal language of contracts, the legal language of petitions, the legal language of judgements, the legal language of last wills and testaments, the legal language of powers of attorney, academic legal language, and so on (a similar view is shared by Mattila 2006, Cao 2007, Galdia 2009). The results of the analysis of the variation of American legal language undertaken by him support that hypothesis.

In accordance with the state of the art in legal translation studies, translators should follow the rules of formulating texts in a specific legal genre in the target language in order to render translations understandable and natural. Thus, what is required from legal translators is an in-depth knowledge of the structure and lexis typical of such texts.

For instance, there are no borrowings in the Polish statutory language. It is a long-lasting tradition dating back to the inter-war period when the Polish Codification Commission was established to prepare legislation in the Polish language (after 123 years of occupation by Austria, Prussia and Russia). The members of the Commission decided to prepare legislation in Polish and to avoid borrowings. Therefore, the borrowings from Latin, which are very popular in judgments, academic books and papers 
and so on, are not used in Polish statutes. For instance, among very popular Latin terms recognised worldwide one may find bona fide and mala fide. The Latin terms, however, are not used in Polish legislation but their Polish counterparts, being dobra wiara and zta wiara respectively, are used in the Polish Civil Code and the Polish Code of Civil Procedure.

The situation in respect of borrowings may change in Poland under the influence of EU legislation. The Polish language versions of EU directives and regulations contain borrowings both assimilated and non-assimilated from English (e.g. forum shopping), French (e.g. acquis communautaire) and Latin (e.g. kommorienci).

\subsubsection{Parameter of branch of law. Branch-of-law-dependent synonymy}

Synonymous terms may also occur in various branches of law. However, an in-depth analysis usually reveals that they are only quasi-synonymous as they refer to similar but not identical referents. Among such quasisynonymous terms we may enumerate English names for court decisions ending proceedings such as: a judgment, a decree, a verdict, an award. The differences may seem insignificant for distant recipients of messages but may be of vital importance to close recipients. For instance a judgment is a court decision issued in the light of common law, whereas a decree is issued in the light of equity. A verdict is given by a jury and an award by an arbitral tribunal, which may not even be treated as a court in some countries.

\section{Concluding remarks}

The list of parameters discussed in this paper is by no means exhaustive and serves only illustrative purposes. The research into the relation of synonymy at the intralingual is a starting point for the analysis of the same relation at the interlingual level. However, in order to start talking about interlingual synonymy, one first needs to be aware of the complexity of this relation at an intralingual level. Numerous communication problems are in fact a result of translators being unaware that the relation of absolute synonymy is almost non-existent and terms usually have similar meanings but are rarely identical in this respect. In many communicative situations such differences in meaning do not affect communication process significantly. However, in the case of legal or medical communication imprecise messages may result in disastrous consequences for the communication process participants. 


\section{N O T E S}

1 The research financed from the research grant no. DEC-2012/07/E/HS2/00678, titled: Parametrisation of legilinguistic translatology in the scope of civil law and civil procedure awarded by the National Science Centre of the Republic of Poland (Sonata Bis program).

2 The terms were extracted by and presented in a speech delivered by Paula Grządko during the Conference "Polish language of the Legislator - New Challenges" in Warsaw on 24th April 2015.

\section{R E F E R E N C E S}

Alcaraz Varó, E. \& Hughes, B. (2002). Legal Translation Explained. Manchester: S. Jerome Publishing.

Bańczerowski, J. \& Matulewska, A. (2012). Towards the Foundations of Legilinguistic Translatology. In P. Grzegorczyk, K. Knoppek \& M. Walasik (eds.), Proces cywilny. Nauka - Kodyfikacja-Praktyka. Ksiega jubileuszowa dedykowana Profesorowi Feliksowi Zedlerowi (pp. 1225-1261). Warszawa: Wolters Kluwer Polska.

Bańczerowski, J. (1996). A Formal Approach to a General Theory of Language. In R. Sackermann (ed.), Theoretical Linguistics and Grammatical Description. Papers in Honour of Hans-Heinrich Lieb. Current Issues in Linguistic Theory 138. Amsterdam/Philadelphia: John Benjamins Publishing Company.

Bańczerowski, J. (2001). The Linguistic Legacy of Ludwik Zabrocki. In St. Puppel (ed.), The Ludwik Zabrocki Memorial Lecture (pp. 9-49). Poznań: Adam Mickiewicz University.

Berk-Seligson, S. (1999). The impact of court interpreting on the coerciveness of leading questions. In International Journal of Speech Language and the Law, vol. 6, No. 1 (1999).

Bogusławski, A. (1986). O pojęciu wyjaśniania i wyjaśnianiu w lingwistyce. Biuletyn Polskiego Towarzystwa Językoznawczego. XL, 45-51.

Cao, D. (2007). Translating Law. Clevedon: Multilingual Matters Ltd.

Cheshire, J. (ed.). (1994). English around the World. Sociolinguistic Perspectives. Cambridge: Cambridge University Press.

Crystal, D. (1985). How Many Millions? The Statistics of English Today. English Today 1, 7-11.

Delisle J. et al. (eds.) (1999). Translation Terminology. Amsterdam/Philadelphia: John Benjamins Publishing Company.

Galdia, M. (2009). Legal Linguistics. Frankfurt am Main: Peter Lang Publishing House.

Goddard, Ch. (2009). Where Legal Cultures Meet: Translating Confrontation into Coexistence. Investigationes Linguisticae vol. XVII, 168-205.

Grøn, H. (1992). Legal Language and the Legal Translator. Hermes, Journal of Linguistics no. 9, 113-139. 
Jackob, J. I. H. (1995). Atkin's Encyclopaedia of Court Forms in Civil Proceedings. Volume 10. Companies - Winding-up. London: Butterworths.

Jakubecki, A., Zedler F. (2003). Prawo upadłościowe i naprawcze. Komenatrze Zakamycza. Kraków: Zakamycze.

Jopek-Bosiacka, A. (2010). Legal Communication: A Cross-Cultural Perspective. Warsaw: Warsaw University Press.

Keay, A., Walton P. (2003). Insolvency Law: Corporate and Personal. London: Pearson Education Limited.

Kielar, B. Z. (1996). Na manowcach tłumaczenia tekstu prawnego: prawdopodobieństwo wywołania szoku kulturowego. In F. Grucza \& K. Chomicz-Jung (eds.), Problemy komunikacji interkulturowej. Jedna Europa - wiele języków i wiele kultur (pp. 135-141). Warszawa: Wydawnictwo Uniwersytetu Warszawskiego.

Kierzkowska, D. (2002). Tłumaczenie prawnicze. Warszawa: Wydawnictwo TEPIS.

Kierzkowska, D. (ed.) (2011). Kodeks Ttumacza Przysieglego z komentarzem. Warszawa: Wydawnictwo Translegis.

Kubacki, A. D. (2012). Tłumaczenie poświadczone. Status, kształcenie, warsztat $i$ odpowiedzialność tlumacza przysiegłego. Warszawa: Wolters Kluwer Business.

Kubacki, A. D. (2013). Teksty paralelne jako narzędzie pomocnicze przy sporządzaniu tłumaczeń specjalistycznych. Comparative Legilinguistics 20013/13, 137-148.

Łętowska Ewa (ed.) (2013). Prawo zobowiazań - część ogólna, Warszawa: C.H. Beck.

Lewandowska-Tomaszczyk, B. (2005). Podstawy językoznawstwa komputerowego. Łódź: Wydawnictwo Uniwersytetu Łódzkiego.

Marsh, D. (2004). Bankruptcy, Insolvency and the Law. A Comprehensive Guide to All Aspects of Bankruptcy and Insolvency. Revised Edition. Brighton: Easyway Guides.

Mattila, H. (2006). Comparative Legal Linguistics. England: Ashgate.

Mattila, H. (2013). Comparative Legal Linguistics. England: Ashgate.

Matulewska, A. (2007). Lingua Legis in Translation. Frankfurt am Main, Germany: Peter Lang Publishing House.

Matulewska, A. (2013). Legilinguistic Translatology. A Parametric Approach to Legal Translation. Frankfurt am Main, Germany: Peter Lang Publishing House.

Matulewska, A., Nowak, P. (2006). Polskie sprawozdanie finansowe w tłumaczeniu na francuski. Lingua Legis no. 14, 65-71.

Neubert, A. (1996). Text linguistics of Translation: The Textual Approach to Translation. In R. M. Gaddis (ed.), Translation Horizons Beyond the Boundaries of Translation Spectrum. Translation Perspectives IX (pp. 87-105). Binghamton: Center for Research in Translation. 
Newmark, P. (1982). Approaches to Translation. Oxford: Pergamon Press Ltd.

Newmark, P. (1988). A Textbook of Translation. UK: Prentice Hall International Ltd.

Newmark, P. (1991). About Translation. Clevedon: Multilingual Matters Ltd.

Popiołek Wojciech (ed.) (2013). Międzynarodowe prawo handlowe, Warszawa: C.H. Beck.

Rajak, H. (1991). Insolvency Law. Theory and Practice. London: Sweet \& Maxwell.

Rayar, L. (1992). Translating Law: Method or Madness? In J. Miller (ed.), International Forum of Legal Translation 1992. Proceedings (pp. 62-71). Warszawa: Wydawnictwo TEPIS.

Roald J., Whittaker S. (2010). Verbalisation in French and Norwegian Legislative Texts: A Contrastive Case Study. In M. Gotti \& Ch. Williams (eds.), Legal Discourse Across Languages and Cultures. Linguistic Insights 117 (pp. 95107). Bern: Peter Lang.

Šarčević, S. (2000). New Approach to Legal Translation. The Hague: Kluwer Law International.

Smith, S. A. (1995). Culture Clash: Anglo-American Case Law and German Civil Law in Translation. In M. Morris (ed.), Translation and the Law (pp. 181197). American Translators Association Scholarly Monograph Series, vol. VIII, 1995. Amsterdam/Philadelphia: John Benjamins Publishing Company.

Tolmie, F. (1998). Introduction to Corporate and Personal Insolvency Law. London: Sweet \& Maxwell.

Vermeer, H. J. (2001). Skopos and Commission in Translational Action. In L. Venuti \& M. Baker (eds.), The Translation Studies Reader (pp. 221-232). London, New York: Routledge.

Vinay, J.-P., Darbelnet J. (1966). Stylistique comparée du français et de l'anglais. Paris: Didier.

Winter, R. J. (2012). What did he say? Mistranslations in the court. In: Judicial Notebook. Retrieved July 2013 from http://www.apa.org/monitor/2012/03/ jn.aspx

Zabrocki, L. (1963). Wspólnoty komunikatywne $w$ genezie $i$ rozwoju języka niemieckiego. Część I. Prehistoria języka niemieckiego. Wrocław, Warszawa, Kraków: Zakład Narodowy imienia Ossolińskich Wydawnictwo Polskiej Akademii Nauk.

Zedler, F. (2004). Prawo upadłościowe i naprawcze w zarysie. Kraków: Zakamycze.

\section{Selected source texts}

Act of $10^{\text {th }}$ July 1952 on Copyright [Ustawa z dnia 10 lipca 1952 r. w prawie autorskim]. Retrieved April 2015 from the website of Kancelaria Sejmu http://isap.sejm.gov.pl/DetailsServlet?id=WDU19520340234 


\section{Aleksandra Matulewska}

Act of $28^{\text {th }}$ February 2003 Law of Insolvency and Rehabilitation [Ustawa z dnia 28 lutego 2003. Prawo upadłościowe i naprawcze]. Retrieved June 2013 from the website of Kancelaria Sejmu http://isap.sejm.gov.pl/DetailsServlet?id= WDU20030600535.

Act of $28^{\text {th }}$ July 2005 on the amendment of the Code of Civil Procedure [Ustawa z dnia 28 lipca 2005 r. o zmianie Ustawy - Kodeks postępowania cywilnego]. Retrieved April 2015 from the website of Kancelaria Sejmu http://isap. sejm.gov.pl/DetailsServlet?id=WDU20051781478.

Act of $29^{\text {th }}$ March 1926 on Copyright [Ustawa z dnia 29 marca 1926 r. o prawie autorskim]. Retrieved April 2015 from the website of Kancelaria Sejmu http://isap.sejm.gov.pl/DetailsServlet?id=WDU19260480286.

Act of $4^{\text {th }}$ February 1994 on Copyright and Neighbouring Rights [Ustawa o prawie autorskim i prawach pokrewnych z dnia 4 lutego 1994 roku]. Retrieved April 2015 from the website of Kancelaria Sejmu http://isap.sejm.gov.pl/ DetailsServlet?id=WDU19940240083.

Civil Code of 1964 of 23 April 1964 [Ustawa Kodeks Cywilny z dnia 23 kwietnia 1964 r.]. Retrieved April 2015 from the website of Kancelaria Sejmu http://isap.sejm.gov.pl/DetailsServlet?id=WDU19640160093.

Code of Civil Procedure of 17 November 1964 [Ustawa Kodeks postępowania cywilnego z dnia 17 listopada 1964 r.]. Retrieved April 2015 from the website of Kancelaria Sejmu http://isap.sejm.gov.pl/DetailsServlet?id=WDU19640430 296.

Code of Commercial Partnerships and Companies of $15^{\text {th }}$ September 2000 [Ustawa z dnia 15 września 2000 r. Kodeks spółek handlowych]. Retrieved June 2013 from the website of Kancelaria Sejmu http://isap.sejm.gov.pl/DetailsServlet? id=WDU20000941037.

European Council Regulation (EC) No 1346/2000 on insolvency proceedings. Retrieved June 2013 from Eur-Lex http://eur-lex.europa.eu/LexUriServ/ LexUriServ.do?uri=OJ:L:2000:160:0001:0018:en:PDF.

Insolvency Act 1986. Retrieved June 2013 from HMS government website: http:// www.insolvency.gov.uk/insolvencyprofessionandlegislation/legislation/uk/ insolvencyact.pdf.

Rozporządzenie Rady (WE) nr 1346/2000 z dnia 29 maja 2000 r. w sprawie postępowania upadłościowego. Retrieved June 2013 from Eur-Lex http://eurlex.europa.eu/LexUriServ/LexUriServ.do?uri=OJ:L:2000:160:0001:0018:pl: PDF. 